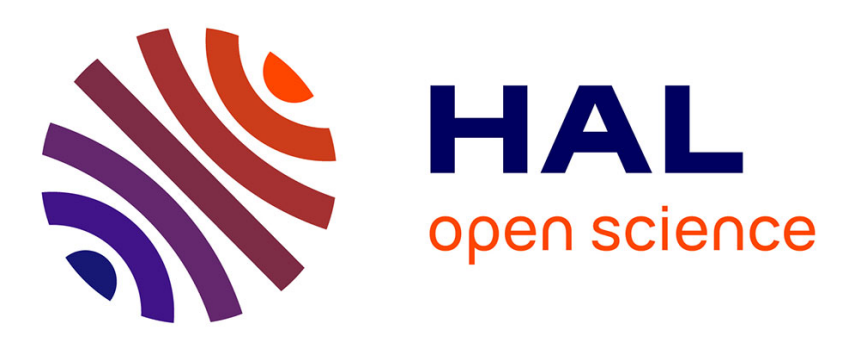

\title{
Variable adhesion of Listeria monocytogenes isolates from food-processing facilities and clinical cases to inert surfaces.
}

Odile Tresse, Kelly Shannon, Anthony Pinon, Pierre Malle, Michele Vialette, Graziella Midelet-Bourdin

\section{To cite this version:}

Odile Tresse, Kelly Shannon, Anthony Pinon, Pierre Malle, Michele Vialette, et al.. Variable adhesion of Listeria monocytogenes isolates from food-processing facilities and clinical cases to inert surfaces.. Journal of Food Protection, 2007, 70 (7), pp.1569-1578. hal-02658268

\section{HAL Id: hal-02658268 \\ https://hal.inrae.fr/hal-02658268}

Submitted on 30 May 2020

HAL is a multi-disciplinary open access archive for the deposit and dissemination of scientific research documents, whether they are published or not. The documents may come from teaching and research institutions in France or abroad, or from public or private research centers.
L'archive ouverte pluridisciplinaire HAL, est destinée au dépôt et à la diffusion de documents scientifiques de niveau recherche, publiés ou non, émanant des établissements d'enseignement et de recherche français ou étrangers, des laboratoires publics ou privés. 


\title{
Variable Adhesion of Listeria monocytogenes Isolates from Food-Processing Facilities and Clinical Cases to Inert Surfaces
}

\author{
ODILE TRESSE, ${ }^{1 *}$ KELlY SHANNON, ${ }^{1}$ ANTHONY PINON, ${ }^{2}$ PIERRE MALLE, ${ }^{3}$ MiCHÈle VIALETTE, ${ }^{2}$ AND \\ GRAZIELLA MIDELET-BOURDIN ${ }^{3}$
}

\begin{abstract}
${ }^{1}$ Institut National de la Recherche Agronomique UR638, 396 rue J. Guesde, B.P. 20039, F-59651 Villeneuve d'Ascq Cedex, France; ${ }^{2}$ Institut Pasteur de Lille, 1 rue du Prof. Calmette, B.P. 245, F-59019 Lille Cedex, France; and ${ }^{3}$ Agence Française de Sécurité Sanitaire des Aliments, Rue Huret Lagache, F-62200 Boulogne-sur-Mer, France
\end{abstract}

MS 06-484: Received 8 September 2006/Accepted 8 March 2007

\begin{abstract}
One hundred one strains of Listeria monocytogenes isolated from seafood and cheese industry samples and from patients with listeriosis were assessed using a microtiter plate method for adhesion to polystyrene and stainless steel surfaces. The adhesion rate for these strains ranged from 3.10 to $35.29 \%$ with an inoculum of $8 \times 10^{8}$ cells per well. A strong correlation was found between adhesion to polystyrene and stainless steel microtiter plates, indicating that the intrinsic ability of $L$. monocytogenes to adhere to inert surfaces is stronger than the influence of the surface's physicochemical properties. The clinical strains were less adherent to inert surfaces than were the industrial strains. By integrating other factors such as location of the industrial strains, contamination type of the clinical strains, serotype, and pulsotype into the analysis, some weak but significant differences were noted. For the industrial isolates, the number of cells attached to both surfaces differed significantly depending on whether they were isolated from food or food-processing environments in the seafood and cheese industry. For clinical isolates, sporadic strains exhibited greater adhesion to polystyrene than did epidemic strains. Strains belonging to the pulsed-field gel electrophoretype clusters A and M (lineages II and I, respectively) were less able to adhere to polystyrene and stainless steel than were strains in the more common clusters.
\end{abstract}

Listeria monocytogenes is a common bacterial contaminant of many foods including fish, seafood, meat, soft cheese, delicatessen products, raw milk, and vegetables (30). Compared with other foodborne pathogens, L. monocytogenes is unique in its resistance to adverse conditions that normally prevent or limit bacterial growth. This pathogen can grow at high salt concentrations, relatively low $\mathrm{pH}$, and refrigeration temperatures (15). The economic impact of $L$. monocytogenes contamination is considerable because of the large number of products recalled for failure to meet strict regulations governing such contamination.

L. monocytogenes has been recovered from a wide range of food contact surfaces and equipment because of the ability of this pathogen to form biofilms (26) and to adhere to inert surfaces in the food-processing environment $(2,11,31)$. Compared with planktonic strains, L. monocytogenes strains in biofilms are more resistant to disinfection procedures $(32,33)$, and these attached cells serve as a reservoir for re- or cross-contamination of foods during manufacture. Adhesion is a crucial step in the contamination process and is defined as the first phase of biofilm formation in which the cells attach to a surface within minutes to hours (6). Hereinafter, the term adhesion will refer only to initial adhesion of bacteria to surfaces.

Adhesion to inert surfaces is a complex process involving van der Waals and electrostatic forces and hydrophobic interactions $(8,25)$. The extent of adhesion is dic-

* Author for correspondence. Tel: 33 (0)2 406878 11; Fax: 33 (0)2 40

6877 62; E-mail: tresse@ vet-nantes.fr. tated by surface composition, charge, and hydrophobicity of the cells and the food contact surface and the roughness (topography) of the contact surface (6). Bacterial adhesion is also influenced by specific cellular or molecular structures on the cell surface, including flagella $(35,38)$. However, data on bacterial adhesion generated from different laboratories vary depending on the cell preparation and adhesion assay methods. Environmental conditions such as temperature, $\mathrm{pH}$, and growth phase also influence the ability of $L$. monocytogenes to adhere to inert surfaces $(4,5,11$, 35). To overcome this bias, Beresford et al. (2) assessed adhesion of L. monocytogenes 10403 to a broad range of materials used in food-processing facilities under the same conditions and concluded that the surface material had a limited role in reducing the spread of $L$. monocytogenes. Adhesion variation also can be attributed to the test strains, as has been shown for adhesion of $L$. monocytogenes to stainless steel $(9,18,23)$. Lunden et al. (23) reported that adhesion was linked to strain persistence. Typing techniques such as serotyping, lysotyping, or ribotyping are less discriminative and reproducible than pulsed-field gel electrophoresis (PFGE). Consequently, PFGE is now widely used for the characterization of $L$. monocytogenes subtypes $(1,19,34)$ when tracing environmental and clinical isolates. Among 26 L. monocytogenes strains recovered from a plant dicing line, Lunden et al. (21) reported that the number of cells adhering to stainless steel was higher for one L. monocytogenes pulsotype (type I; 20 strains) than other pulsotypes (types II, III, and IV; 6 strains). However, the methods 
used for adhesion assays were time-consuming, which limited the number of strains that could be tested for adhesion. To screen a broad range of strains for adhesion to inert surfaces, a simple and rapid technique was recently adapted for use with 96-well microtiter plates (35).

In this study, we assessed 101 L. monocytogenes strains for differences in adhesion to two common food contact surfaces, polystyrene and stainless steel. A 96-well microtiter plate method was used to evaluate adhesion capability based on strain origin (seafood industry, cheese industry, or clinical cases), sampling location (food, food-processing environment), type of human isolate (sporadic or epidemic), serotype, and pulsotype.

\section{MATERIALS AND METHODS}

Strains. The 101 L. monocytogenes strains were provided by Institut Pasteur (Lille, France) and Agence Française de Sécurité Sanitaire des Aliments (AFSSA; Boulogne-sur-mer, France). Of these 101 strains, 38 were isolated from seafood plants (21 from seafoods and 17 from the plant environment) in France between 1997 and 2003, 28 were isolated from cheese plants (12 from cheeses and 16 from the plant environment) in France in 2000, and 35 were worldwide isolates from sporadic (18 cases) and epidemic (17 cases) listeriosis cases. The strains were received in cryotubes or gelose tubes and stored at $-20^{\circ} \mathrm{C}$. All strains isolated in France by Institut Pasteur and AFSSA came from the first culture after isolation of the strains. Each strain was subcultured in Trypticase soy broth supplemented with $6 \mathrm{~g} /$ liter yeast extract (TSBYE; Biokar Diagnostics, Beauvais, France), aliquoted in 1.5$\mathrm{ml}$ tubes in fresh sterile TSBYE supplemented with $20 \%$ glycerol, and stored as stock cultures at $-20^{\circ} \mathrm{C}$.

Strain serotyping. Strains of unknown serotype were characterized using multiplex PCR as described by Doumith et al. (14) with the following modifications. The DNA fragments targeting the five genes (Imo0737, lmo1118, ORF2819, ORF2110, and prs) were amplified from one colony of each strain grown on plates of Trypticase soy agar supplemented with 6 g/liter yeast extract (TSAYE; Biokar Diagnostics) for $24 \mathrm{~h}$ at $37^{\circ} \mathrm{C}$ and resuspended in $50 \mu \mathrm{l}$ of sterile water. L. monocytogenes strains Scott A, X-Limo 500, X-Li-mo 538, and GP7 were selected as controls for serotypes $4 b, 1 / 2 a, 1 / 2 c$, and $1 / 2 b$, respectively. PCRs were performed with an initial denaturation step at $94^{\circ} \mathrm{C}$ for $5 \mathrm{~min} ; 35$ cycles at $94^{\circ} \mathrm{C}$ for $0.40 \mathrm{~min}, 53^{\circ} \mathrm{C}$ for $1.15 \mathrm{~min}$, and $72^{\circ} \mathrm{C}$ for 1.15 min; and 1 final cycle at $72^{\circ} \mathrm{C}$ for $7 \mathrm{~min}$ in a mastercycler personal thermocycler (Eppendorf, Sartrouville, France). The PCR products were separated as described by Doumith et al. (14).

PFGE and cluster analysis. Each strain was grown on TSAYE for $24 \mathrm{~h}$ at $37^{\circ} \mathrm{C}$. Bacterial cells were suspended in 2.5 $\mathrm{ml}$ of TE buffer (10 mM Tris-HCl, pH 8, and $1 \mathrm{mM}$ EDTA), and the cell density was adjusted to an optical density (OD) of 1.3 at $610 \mathrm{~nm}$. PFGE was performed as described by Graves and Swaminathan (16). The standardized cell suspension $(240 \mu \mathrm{l})$ was transferred to a $1.5-\mathrm{ml}$ microcentrifuge tube and incubated with $60 \mu \mathrm{l}$ of $10 \mathrm{mg} / \mathrm{ml}$ lysozyme solution. A 50\% agarose solution of the cell suspension was aliquoted $(100 \mu \mathrm{l})$ into a plug mold (BioRad, Marne La Coquette, France). The agarose plugs were then incubated in lysis solution $(50 \mathrm{mM}$ Tris- $\mathrm{HCl}, \mathrm{pH} 8,50 \mathrm{mM}$ EDTA, $1 \%$ sodium lauryl sarcosine, and $150 \mu \mathrm{g} / \mathrm{ml}$ proteinase $\mathrm{K}$ ) in an orbital shaker water bath $(100 \mathrm{rpm})$ at $54^{\circ} \mathrm{C}$ for $2 \mathrm{~h}$, washed with sterile distilled water at $50^{\circ} \mathrm{C}$ and then with $\mathrm{TE}$ buffer at $50^{\circ} \mathrm{C}$, cut into four pieces, and then stored in TE buffer at $4^{\circ} \mathrm{C}$ until digestion.

DNA was digested with ApaI (New England Biolabs, Ozyme, Saint-Quentin en Yvelines, France) or AscI (New England Biolabs) according to the manufacturer's instructions. The macrorestriction fragments generated by ApaI were separated in a $1.2 \%$ (wt/vol) agarose gel in $0.5 \times$ TBE solution (45 mM Tris, $45 \mathrm{mM}$ boric acid, and $1 \mathrm{mM}$ EDTA) at $14^{\circ} \mathrm{C}$ in a CHEF-DRIII device (Bio-Rad) at a $120^{\circ}$ angle, a gradient of $7.6 \mathrm{~V} / \mathrm{cm}^{2}$, and pulse times from 15 to $35 \mathrm{~s}$ for $9 \mathrm{~h}$ then 2 to $20 \mathrm{~s}$ for $15 \mathrm{~h}$. The macrorestriction fragments generated by $A s c \mathrm{I}$ were separated in a $1.0 \%$ (wt/vol) agarose gel in $0.5 \times \mathrm{TBE}$ solution at $14^{\circ} \mathrm{C}$ in the CHEF-DRIII device at a $120^{\circ}$ angle, a gradient of $7.6 \mathrm{~V} / \mathrm{cm}^{2}$, and pulse times from 10 to $45 \mathrm{~s}$ for $20 \mathrm{~h}$. The cluster E strains were digested with ApaI and run using pulse times from 2 to $20 \mathrm{~s}$ for $15 \mathrm{~h}$ and then 2 to $8 \mathrm{~s}$ for $9 \mathrm{~h}$. A Lambda Ladder PFG Marker (New England Biolabs) was used on each gel as a molecular weight marker (50 to $1,000 \mathrm{~kb}$ ). Gels were stained with $1 \mu \mathrm{g} / \mathrm{ml}$ ethidium bromide, photographed with a Gel Doc 1000 video system (Bio-Rad), and analyzed with Bionumerics software (Applied Maths, Sint-Martens-Latem, Belgium). The similarity index between PFGE banding profiles was calculated based on Dice's coefficient (position tolerance of 1.2\%) (12), and the dendrogram was constructed using UPGMA (unweighted pair group method with arithmetic averages).

Growth rate and stationary phase determination. The stock bacterial culture $(400 \mu \mathrm{l})$ was added to $2 \mathrm{ml}$ of TSBYE and incubated at $20^{\circ} \mathrm{C}$ for $8 \mathrm{~h}$. Half of the 8 -h subculture was transferred to $10 \mathrm{ml}$ of TSBYE and incubated at $20^{\circ} \mathrm{C}$ overnight. This subculture was then used to assess the growth rate of each strain. Growth curves were obtained using a Bioscreen $\mathrm{C}$ plate reader (Thermo Life Science, Cergy-Pontoise, France). From the 10-ml overnight subculture, $1.5 \mathrm{ml}$ was centrifuged at $13,000 \times g$ for $20 \mathrm{~min}$ at $20^{\circ} \mathrm{C}$ and resuspended in $1.5 \mathrm{ml}$ of TSBYE. The OD of the culture was measured at $550 \mathrm{~nm}$ and converted into CFUs per milliliter using a calibration curve from L. monocytogenes strains Scott A, EDGe, and X-Li-mo 500. Each culture was diluted in TSBYE to obtain $5 \times 10^{6} \mathrm{CFU} / \mathrm{ml}$ and distributed in $10 \mathrm{rep}$ licates in the wells of a sterile Bioscreen honeycomb plate (Thermo Life Science). Growth was monitored at $20^{\circ} \mathrm{C}$ for $24 \mathrm{~h}$ by hourly measurement of the OD at 420 to $580 \mathrm{~nm}$.

Results obtained from the Bioscreen $\mathrm{C}$ were used to determine the maximum growth rate from the mean of the 10 replicates. The value corresponding to the time needed to reach the stationary phase $+25 \%$ was also determined for the adhesion assays.

Stainless steel microtiter plate passivation, cleaning, and disinfection. Two 96-well stainless steel 316L microtiter plates were manufactured by MECA-CN (Widehem, France). Dimensions of each plate were 127 by 86 by $15 \mathrm{~mm}$, and each flatbottom cylindrical well had a diameter of $6.4 \pm 0.02 \mathrm{~mm}$ and a height of $11 \pm 0.02 \mathrm{~mm}$ for a capacity of $0.35 \mathrm{ml}$. The wells were manufactured at a numerical machining center (KRYLE, Stoke-on-Trent, UK) with new tools for each plate. The roughness in and outside the wells ranged between 0.5 and $0.8 \mu \mathrm{m}$. The bottom diameter of the well, the number of wells, the space between the wells, and the dimension of the stainless steel plate were identical to those aspects of commercial 96-well polystyrene microtiter plates (Greiner bio-one, Courtaboeuf, France). Consequently, both adhesion assays could be performed with the same equipment (a Tecan Colombus washer and high channel multipipets). Before the first use, each stainless steel microtiter plate was subjected to a surface passivation and a cleaning-disinfecting cy- 
cle. Surface passivation was accomplished by incubating the stainless microtiter plates for $1 \mathrm{~h}$ in $4 \mathrm{~N} \mathrm{HNO}_{3}{ }^{-}$at $50^{\circ} \mathrm{C}$ followed by 10 rinses with distilled water. The cleaning-disinfecting cycle involved cleaning the wells five times with $95 \%$ ethanol and then incubating the plate at $60^{\circ} \mathrm{C}$ for $1 \mathrm{~h}$ in a $5 \%$ commercial surfactant solution RBS 35 (Traitements chimiques de surfaces SARL, Frelinghien, France), which is commonly used to clean food contact surfaces. After a final rinse with distilled water, the stainless steel plates were air dried and autoclaved at $121^{\circ} \mathrm{C}$ for $20 \mathrm{~min}$ in a 1liter Nalgene beaker. After each adhesion assay, the stainless steel plates were immersed in water and autoclaved for $1 \mathrm{~h}$ at $121^{\circ} \mathrm{C}$. The wells were swabbed with $5 \%$ RBS 35 , and the plates were sonicated for $30 \mathrm{~min}$ at $40 \mathrm{kHz}$ in an ultrasound bath 2510 (Branson, Annemasse, France). The final washing step was the same cleaning-disinfecting cycle as described above.

Bacterial adhesion to polystyrene and stainless steel. For the adhesion assay, $0.8 \mathrm{ml}$ of the 10 - $\mathrm{ml}$ subculture was added to $40 \mathrm{ml}$ of sterile TSBYE, shaken in a rotary shaker at $150 \mathrm{rpm}$, and incubated at $20^{\circ} \mathrm{C}$ until the culture reached stationary phase plus an additional $25 \%$ of the incubation time to reach this phase. Each bacterial culture was centrifuged at $3,000 \times g$ for $20 \mathrm{~min}$ at $20^{\circ} \mathrm{C}$. The cell pellet was washed with $30 \mathrm{ml}$ of tryptone salt (TS; $8.5 \mathrm{~g} /$ liter tryptone and $1 \mathrm{~g} /$ liter $\mathrm{NaCl}$ ), centrifuged at 3,000 $\times g$ for $20 \mathrm{~min}$ at $20^{\circ} \mathrm{C}$, and resuspended in $10 \mathrm{ml}$ of TS supplemented with chloramphenicol at a subbactericidal concentration (100 $\mu \mathrm{g} / \mathrm{ml})$ to prevent further cell growth, multiplication, and adaptation during the assay (35). The bacterial adhesion assays were performed in six replicates in 96-well sterile polystyrene and stainless steel $316 \mathrm{~L}$ microtiter plates according to the protocol previously described by Tresse et al. (35) with the following modifications. Adhesion assays were conducted in TS medium supplemented with $100 \mu \mathrm{g} / \mathrm{ml}$ chloramphenicol. Cells numbers were estimated using the previously described $\mathrm{OD}_{550 \mathrm{~nm}}$ calibration curve to obtain $8 \times 10^{8}$ cells per well with cell numbers confirmed by spiral plating on Oxford and TSAYE (DS, Interscience, Saint-Nom, France) followed by incubation at $37^{\circ} \mathrm{C}$ for $24 \mathrm{~h}$. These plate counts eliminated any OD bias due to cells of different sizes. The initial bacterial populations were calculated from the mean of colonies enumerated on both Oxford and TSAYE (i.e., six replicates); there was no difference in results obtained with these two media for each strain. The attached cells were stained with crystal violet, and the number of attached cells $(Y)$ was determined from a calibration curve that represents the correlation between the number of cells and the crystal violet intensity at $\mathrm{OD}_{595 \mathrm{~nm}}$ as described previously (29). The percentage of attached cells was calculated with the following equation: attached cells $(\%)=(Y / X) \times 100$.

The 101 L. monocytogenes strains were tested for adhesion, and then two to four independent adhesion assays were conducted on 32 and 30 randomly selected strains with polystyrene and stainless steel microtiter plates, respectively.

Measurement of contact angle using goniometry. Contact angle measurements were obtained only for the stainless steel microtiter plate because these values were determined previously for polystyrene surfaces (35). Contact angle was determined with a goniometer Digidrop ASE (GBX Instruments, Romans, France) driven by Windrop ++ software (GBX Instruments) to determine the hydrophobicity-hydrophilicity and microtiter plate surface charge. Young's equation and van Oss's model (37) were used. Young's equation describes the relationship of the measurable liquid surface tension $\gamma_{L}$, the contact angle $\theta$, the solid surface free energy $\gamma_{S}$, and the interfacial energy $\gamma_{S L}: \gamma_{L} \cos \theta=\gamma_{S}-\gamma_{S L}$. The mathematical approach of van Oss et al. (37) was chosen to determine both Lifshitz-van der Waals $\left(\gamma_{\mathrm{S}}{ }^{\mathrm{LW}}\right)$ and Lewis acidbase parameters $\left(\gamma_{\mathrm{S}}{ }^{-}, \gamma_{\mathrm{S}}{ }^{+}\right)$. The results were expressed as the mean of triplicate contact angles for calibrated drops of three liquids (water, formamide, and diiodomethane).

Statistical analyses. Analyses of adhesion data were performed with the statistical software S-PLUS 2000 (MathSoft, Seattle, Wash.). Paired Student $t$ tests were used to compare the means of adhesion for each variable. Analyses of variance were conducted to account for the effects on adhesion of all variables and their interactions. Distribution of adhesion among the strains also was described with box and whisker plots (36). Differences were considered not significant at $P>0.05$ and were considered significant at $P<0.001$.

\section{RESULTS}

Strain characterization and growth. The 101 L. monocytogenes strains were characterized by serotyping and pulsotyping (Tables 1 and 2). The seafood isolates primarily belonged to L. monocytogenes serotypes $1 / 2 \mathrm{a}$ or $3 \mathrm{a}$, the cheese isolates belonged to serotypes $1 / 2 b$ or $3 b$, and the clinical isolates belonged to serotypes $4 \mathrm{~b}$. PFGE fingerprinting revealed 52 different pulsotypes obtained from 47 unique restriction patterns with ApaI and 44 patterns with AscI (Fig. 1). Cluster analysis indicated that these 52 pulsotypes could be grouped into 14 distinct clusters, with $77 \%$ similarity based on the Dice index. Seven different clusters were found among the strains isolated from either the seafood or cheese industries, and 10 were found among the clinical isolates (Table 2). Only one cluster $(F)$ was common to the seafood industry, the cheese industry, and the clinical strains. Four clusters (A, C, F, and K) were common to the seafood industry and the clinical isolates, six (F, H, J, L, M, and N) were common to the cheese industry and the clinical isolates, and one $(\mathrm{F})$ was common to the seafood industry and the cheese industry. Ten or more strains were classified in clusters A, C, G, K, M, and $\mathrm{N}$. The pulsotypes could be divided in two lineages. Lineage I (49 strains) was composed of strains of serotypes $1 / 2 b, 3 b, 4 b$, and $4 \mathrm{e}$ representing pulsotype clusters $\mathrm{J}$ to $\mathrm{N}$, except strain DA236 whose serotype was $1 / 2$ a and pulsotype was cluster K. Lineage II (52 strains) was composed of serotypes $1 / 2 \mathrm{a}, 3 \mathrm{a}$, and $1 / 2 \mathrm{c}$ representing pulsotype clusters A to I (Fig. 1).

Overall, the bacterial growth rates varied from 0.17 to $0.40 \mathrm{~h}^{-1}$ with a mean of $0.30 \pm 0.05 \mathrm{~h}^{-1}$ for all strains. No significant difference $(P>0.05)$ was noted between the average growth rate of strains isolated from the seafood industry $\left(0.29 \pm 0.05 \mathrm{~h}^{-1}\right)$, cheese industry $(0.29 \pm 0.04$ $\left.\mathrm{h}^{-1}\right)$, and clinical cases $\left(0.31 \pm 0.04 \mathrm{~h}^{-1}\right)$.

Material surface characterization. The adhesion assays were conducted using sterile 96-well polystyrene and stainless steel $316 \mathrm{~L}$ microtiter plates that were inoculated to contain $8 \times 10^{8}$ cells per well and then incubated $4 \mathrm{~h}$ at $20^{\circ} \mathrm{C}$. The hydrophobic-hydrophilic character and the charge of the stainless steel microtiter plate surface also were determined. The contact angles were $66.5 \pm 0.25^{\circ}$, $63.4 \pm 0.25^{\circ}$, and $52.7 \pm 0.17^{\circ}$ for water, formamide, and diiodomethane, respectively. The resulting free surface en$\operatorname{ergy}\left(\gamma_{\mathrm{S}}{ }^{\text {tot }}\right)$ was $34.8 \mathrm{~mJ} / \mathrm{m}$ with a Lifshitz-van der Waals 
TABLE 1. Serotype and pulsotype characterization of $101 \mathrm{~L}$. monocytogenes strains isolated from diverse sampling locations at seafood and cheese facilities and from patients with listeriosis

\begin{tabular}{|c|c|c|c|c|c|c|c|c|c|c|c|}
\hline \multicolumn{4}{|c|}{ Seafood } & \multicolumn{4}{|c|}{ Cheese } & \multicolumn{4}{|c|}{ Patients } \\
\hline Strain & Source $^{a}$ & Serotype & $\begin{array}{l}\text { Pulso- } \\
\text { type } \\
\text { cluster }\end{array}$ & Strain & Source $^{a}$ & Serotype & $\begin{array}{l}\text { Pulso- } \\
\text { type } \\
\text { cluster }\end{array}$ & Strain & Source $^{b}$ & Serotype & $\begin{array}{l}\text { Pulso- } \\
\text { type } \\
\text { cluster }\end{array}$ \\
\hline B1261 & France Fo & $1 / 2 \mathrm{a}$ & $\mathrm{C}$ & X-Li-Mo 506 & France Fo & $4 \mathrm{e}$ & $\mathrm{L}$ & $00 / 09 / 01-4$ & Denmark Ep & $4 \mathrm{~b}$ & M \\
\hline B7200 & France Fo & $1 / 2 \mathrm{a}$ or $3 \mathrm{a}$ & G & X-Li-Mo 509 & France Fo & $4 \mathrm{e}$ & $\mathrm{J}$ & $00 / 09 / 01-5$ & Denmark Ep & $4 \mathrm{~b}$ & M \\
\hline C943 & France Fo & $1 / 2 a$ or $3 a$ & G & X-Li-Mo 511 & France Fo & $4 \mathrm{e}$ & M & 00/09/01-6 & Denmark Ep & $4 \mathrm{~b}$ & M \\
\hline C1635 & France Fo & $1 / 2 \mathrm{~b}$ & $\mathrm{~K}$ & X-Li-Mo 519 & France Fo & $4 \mathrm{e}$ & $\mathrm{L}$ & $00 / 09 / 01-7$ & Denmark Ep & $4 \mathrm{~b}$ & M \\
\hline C5134 & France Fo & $1 / 2 \mathrm{a}$ or $3 \mathrm{a}$ & G & X-Li-Mo 520 & France Fo & $1 / 2 b$ or $3 b$ & $\mathrm{~N}$ & 00/09/08-1 & Sweden Ep & $4 \mathrm{~b}$ & M \\
\hline C5275 & France Fo & $1 / 2 \mathrm{a}$ & A & X-Li-Mo 525 & France Fo & $1 / 2 \mathrm{~b}$ & $\mathrm{~N}$ & $00 / 09 / 08-2$ & Sweden Ep & $4 b$ & $\mathrm{~J}$ \\
\hline CL86 & France Fo & $1 / 2 a$ or $3 a$ & A & X-Li-Mo 528 & France Fo & $1 / 2 b$ & $\mathrm{~N}$ & 00/09/08-3 & Sweden Ep & $4 \mathrm{~b}$ & M \\
\hline CL297 & France Fo & $1 / 2 a$ or $3 a$ & A & X-Li-Mo 529 & France Fo & $1 / 2 b$ & $\mathrm{~N}$ & 00/09/08-4 & Sweden Ep & $4 \mathrm{~b}$ & M \\
\hline CPL631 & France Fo & $1 / 2 \mathrm{a}$ & $\mathrm{C}$ & X-Li-Mo 530 & France Fo & $1 / 2 b$ & $\mathrm{~N}$ & 00/09/08-6 & Sweden Ep & $1 / 2 \mathrm{a}$ & $\mathrm{F}$ \\
\hline D3289 & France Fo & $1 / 2 a$ or $3 a$ & $\mathrm{C}$ & X-Li-Mo 531 & France Fo & $4 \mathrm{e}$ & M & $00 / 09 / 21-2$ & New Zealand Ep & $1 / 2 \mathrm{a}$ & $\mathrm{C}$ \\
\hline DA236 & France Fo & $1 / 2 \mathrm{a}$ & $\mathrm{K}$ & X-Li-Mo-533 & France Fo & $1 / 2 \mathrm{~b}$ & $\mathrm{~N}$ & 00/10/17-79 & New Zealand Ep & $4 \mathrm{~b}$ & M \\
\hline DPL1419 & France Fo & $1 / 2 \mathrm{a}$ or $3 \mathrm{a}$ & G & X-Li-Mo 542 & France Fo & $1 / 2 \mathrm{~b}$ & $\mathrm{~L}$ & $00 / 10 / 17-84$ & New Zealand Ep & $1 / 2 \mathrm{a}$ & $\mathrm{C}$ \\
\hline DPF234 & France Fo & $1 / 2 \mathrm{a}$ & I & X-Li-Mo 500 & France Fe & $1 / 2 \mathrm{a}$ & B & $00 / 10 / 17-85$ & New Zealand Ep & $1 / 2 \mathrm{a}$ & $\mathrm{C}$ \\
\hline DSS758 & France Fo & $1 / 2 b$ or $3 b$ & $\mathrm{~K}$ & X-Li-Mo 501 & France $\mathrm{Fe}$ & $1 / 2 \mathrm{a}$ & B & $00 / 10 / 17-88$ & Australia Ep & $1 / 2 b$ or $3 b$ & $\mathrm{~K}$ \\
\hline \multicolumn{12}{|c|}{ DSS1130 } \\
\hline BFA2 & France Fo & $1 / 2 \mathrm{a}$ or $3 \mathrm{a}$ & I & X-Li-Mo 502 & France $\mathrm{Fe}$ & $1 / 2 \mathrm{c}$ & $\mathrm{H}$ & 00/10/17-89 & Australia Ep & $1 / 2 \mathrm{~b}$ & $\mathrm{~K}$ \\
\hline \multicolumn{12}{|c|}{ DSS1130 } \\
\hline BFS2 & France Fo & $1 / 2 b$ or $3 b$ & $\mathrm{~K}$ & X-Li-Mo 514 & France $\mathrm{Fe}$ & $1 / 2 \mathrm{c}$ & $\mathrm{H}$ & Lm ScottA & USA Ep & $4 \mathrm{~b}$ & $\mathrm{~L}$ \\
\hline E1012 & France Fo & $1 / 2 \mathrm{a}$ or $3 \mathrm{a}$ & G & X-Li-Mo 515 & France $\mathrm{Fe}$ & $1 / 2 \mathrm{~b}$ & $\mathrm{~N}$ & Lm EGDe & Germany Ep & $1 / 2 \mathrm{c}$ & $\mathrm{H}$ \\
\hline E3165 & France Fo & $1 / 2 \mathrm{a}$ or $3 \mathrm{a}$ & A & X-Li-Mo 516 & France $\mathrm{Fe}$ & $1 / 2 \mathrm{a}$ or $3 \mathrm{a}$ & B & 00/10/11-1 & Finland Sp & $3 \mathrm{a}$ & A \\
\hline F4125 & France Fo & $1 / 2 \mathrm{a}$ or $3 \mathrm{a}$ & A & X-Li-Mo 527 & France $\mathrm{Fe}$ & $4 \mathrm{e}$ & $\mathrm{J}$ & $00 / 10 / 17-3$ & Canada Sp & $1 / 2 \mathrm{~b}$ & $\mathrm{~K}$ \\
\hline FE191 & France Fo & $1 / 2 \mathrm{a}$ or $3 \mathrm{a}$ & G & X-Li-Mo 536 & France $\mathrm{Fe}$ & $4 \mathrm{e}$ & $\mathrm{L}$ & $00 / 10 / 17-5$ & UK Sp & $1 / 2 \mathrm{~b}$ & $\mathrm{~K}$ \\
\hline GP8 & France Fo & $1 / 2 \mathrm{a}$ & $\mathrm{C}$ & X-Li-Mo 538 & France $\mathrm{Fe}$ & $1 / 2 \mathrm{c}$ & $\mathrm{H}$ & $00 / 10 / 17-7$ & USA Sp & $3 b$ & $\mathrm{~K}$ \\
\hline A4 & France $\mathrm{Fe}$ & $1 / 2 \mathrm{a}$ or $3 \mathrm{a}$ & A & X-Li-Mo 539 & France $\mathrm{Fe}$ & $1 / 2 \mathrm{c}$ & $\mathrm{H}$ & $00 / 10 / 17-8$ & UK Sp & $1 / 2 \mathrm{c}$ & $\mathrm{H}$ \\
\hline B108 & France Fe & $1 / 2 \mathrm{a}$ & A & X-Li-Mo 540 & France $\mathrm{Fe}$ & $4 \mathrm{e}$ & $\mathrm{J}$ & $00 / 10 / 17-9$ & Canada Sp & $4 \mathrm{~b}$ & M \\
\hline B7678 & France $\mathrm{Fe}$ & $1 / 2 \mathrm{a}$ & $\mathrm{G}$ & X-Li-Mo 543 & France $\mathrm{Fe}$ & $1 / 2 \mathrm{a}$ & $\mathrm{F}$ & $00 / 10 / 17-16$ & UK Sp & $1 / 2 \mathrm{~b}$ & $\mathrm{~K}$ \\
\hline CL356 & France $\mathrm{Fe}$ & $1 / 2 a$ or $3 a$ & A & X-Li-Mo 544 & France $\mathrm{Fe}$ & $1 / 2 b$ & $\mathrm{~N}$ & 00/10/06-1 & Italy Sp & $1 / 2 \mathrm{~b}$ & $\mathrm{~N}$ \\
\hline CL101 & France Fe & $1 / 2 a$ or $3 a$ & A & X-Li-Mo 526 & France $\mathrm{Fe}$ & $1 / 2 b$ & $\mathrm{~N}$ & 00/10/06-2 & Italy Sp & $4 \mathrm{~b}$ & $\mathrm{~L}$ \\
\hline CL265 & France $\mathrm{Fe}$ & $1 / 2 \mathrm{a}$ or $3 \mathrm{a}$ & A & X-Li-Mo 537 & France $\mathrm{Fe}$ & $1 / 2 \mathrm{a}$ & B & $00 / 10 / 17-6$ & USA Sp & $1 / 2 \mathrm{~b}$ & $\mathrm{~N}$ \\
\hline CS462 & France $\mathrm{Fe}$ & $1 / 2 \mathrm{a}$ or $3 \mathrm{a}$ & G & X-Li-Mo 541 & France $\mathrm{Fe}$ & $1 / 2 b$ & $\mathrm{~N}$ & $00 / 10 / 17-12$ & UK Sp & $4 \mathrm{~b}$ & $\mathrm{M}$ \\
\hline CS537 & France Fe & $1 / 2 a$ or $3 a$ & G & & & & & $00 / 10 / 17-13$ & USA Sp & $4 \mathrm{~b}$ & $\mathrm{M}$ \\
\hline DS649 & France $\mathrm{Fe}$ & $1 / 2 \mathrm{a}$ or $3 \mathrm{a}$ & G & & & & & $00 / 10 / 17-14$ & USA Sp & $1 / 2 \mathrm{a}$ & $\mathrm{D}$ \\
\hline GP6 & France Fe & $3 b$ & $\mathrm{~K}$ & & & & & 00/10/17-44 & UK Sp & $1 / 2 a$ or $3 a$ & $\mathrm{~F}$ \\
\hline GP7 & France $\mathrm{Fe}$ & $1 / 2 b$ & $\mathrm{~K}$ & & & & & $\mathrm{Lm} \mathrm{C} 1$ & Australia Sp & $1 / 2 \mathrm{~b}$ & $\mathrm{~K}$ \\
\hline GP24 & France $\mathrm{Fe}$ & $1 / 2 \mathrm{a}$ & $\mathrm{C}$ & & & & & $\mathrm{Lm} \mathrm{C} 2$ & New Zealand Sp & $1 / 2 a$ or $3 a$ & $\mathrm{C}$ \\
\hline GP28 & France $\mathrm{Fe}$ & $1 / 2 \mathrm{a}$ & $\mathrm{C}$ & & & & & $\mathrm{Lm} \mathrm{C} 3$ & Sweden Sp & $4 b$ & M \\
\hline Lm E1 & France Fe & $1 / 2 \mathrm{a}$ & $\mathrm{E}$ & & & & & $\mathrm{Lm} \mathrm{C} 4$ & Sweden Sp & $4 \mathrm{~b}$ & $\mathrm{~J}$ \\
\hline Lm E2 & France $\mathrm{Fe}$ & $1 / 2 \mathrm{a}$ & E & & & & & & & & \\
\hline Lm E3 & France $\mathrm{Fe}$ & $1 / 2 \mathrm{a}$ & F & & & & & & & & \\
\hline Lm E4 & France Fe & $1 / 2 \mathrm{a}$ & E & & & & & & & & \\
\hline
\end{tabular}

${ }^{a}$ Fo, directly from food; Fe, from facility environment.

${ }^{b}$ Ep, epidemic strains; Sp, sporadic strains.

energy $\left(\gamma_{\mathrm{S}}{ }^{\mathrm{LW}}\right)$ of $32.7 \mathrm{~mJ} / \mathrm{m}$, a Lewis electron donor energy $\left(\gamma_{\mathrm{S}^{-}}\right)$of $0.0 \mathrm{~mJ} / \mathrm{m}$, and a Lewis electron acceptor energy $\left(\gamma_{\mathrm{s}}{ }^{+}\right)$of $25.0 \mathrm{~mJ} / \mathrm{m}$. These results indicated that the stainless steel microtiter plate surface was slightly hydrophobic and negatively charged.

Adhesion to inert surfaces in general. All adhesion results were expressed as the percentage of attached cells. When an adhesion assay was first conducted on the two autoclaved stainless steel microtiter plates with one strain (L. monocytogenes EGDe), no significant difference in adhesion $(P=0.52)$ was observed in the 96 wells between the two stainless steel plates $(11.47 \% \pm 1.01 \%$ for the first plate and $11.35 \% \pm 1.47 \%$ for the second plate). To estimate the effect of stainless steel cleaning on adhesion, an adhesion test was conducted using three L. monocytogenes strains (EGDe, Xi-Li-mo 500, and Scott A) before and after 22 adhesion-cleaning cycles. Overall, the adhesion-cleaning cycles did not significantly affect adhesion of the three strains $(P=0.38)$; no difference was noted between the two plates after 22 adhesion-cleaning cycles $(P=1.00)$. However, significant differences were observed $(P<$ 0.001 ) between strains on both stainless steel plates before 
TABLE 2. Distribution of 101 L. monocytogenes strains based on serotyping and PFGE cluster analysis

\begin{tabular}{|c|c|c|c|c|}
\hline \multirow[b]{2}{*}{ Grouping } & \multicolumn{4}{|c|}{ No. of isolates } \\
\hline & Seafood & Cheese & Clinical & Total \\
\hline \multicolumn{5}{|l|}{ Serotype (lineage) } \\
\hline $1 / 2 \mathrm{a}$ or $3 \mathrm{a}(\mathrm{II})$ & 34 & 4 & 8 & 45 \\
\hline $1 / 2 \mathrm{c}(\mathrm{II})$ & & 4 & 2 & 7 \\
\hline $1 / 2 b$ or $3 b(I)$ & 4 & 12 & 9 & 25 \\
\hline $4 \mathrm{~b}(\mathrm{I})$ & & & 16 & 16 \\
\hline 4e (I) & & 8 & & 8 \\
\hline Total & 38 & 28 & 35 & 101 \\
\hline \multicolumn{5}{|l|}{ PFGE cluster } \\
\hline $\mathrm{A}$ & 10 & & 1 & 11 \\
\hline $\mathrm{B}$ & & 4 & & 4 \\
\hline $\mathrm{C}$ & 6 & & 4 & 10 \\
\hline $\mathrm{D}$ & & & 1 & 1 \\
\hline $\mathrm{E}$ & 3 & & & 3 \\
\hline $\mathrm{F}$ & 1 & 1 & 2 & 4 \\
\hline G & 10 & & & 10 \\
\hline $\mathrm{H}$ & & 4 & 2 & 6 \\
\hline I & 2 & & & 2 \\
\hline $\mathrm{J}$ & & 3 & 2 & 5 \\
\hline $\mathrm{K}$ & 6 & & 7 & 13 \\
\hline $\mathrm{L}$ & & 4 & 2 & 6 \\
\hline M & & 2 & 12 & 14 \\
\hline $\mathrm{N}$ & & 10 & 2 & 12 \\
\hline Total & 38 & 28 & 35 & 101 \\
\hline
\end{tabular}

and after 22 adhesion-cleaning cycles; there were more attached cells for Scott A than for X-Li-mo 500 and fewer attached cells for EGDe than for X-Li-mo 500. Therefore, it was assumed that the adhesion-cleaning cycles did not affect adhesion of the test strains.

The analyses of variance performed on the complete set of data revealed no significant difference $(P>0.05)$ between the replicates and the independent assays. Overall, the adhesion analyses for all strains indicated that 3.66 to $35.29 \%$ (median, $15.57 \%$ ) and 3.10 to $31.36 \%$ (median, $13.73 \%$ ) of the cells adhered to polystyrene and stainless steel, respectively.

Effect of strain origin, colonized surface, sampling location, and contamination type. Because serotype, pulsotype, and strain origin were not independent variables, strain types (serotype and pulsotype) were analyzed separately from the other variables. Consequently, all strains were first analyzed according to their origin. Then, the clinical strains were separated from the industrial strains (seafood and cheese industries) because one of the test variables was dependent on strain origin (sporadic or epidemic for clinical strains and sampling location for industrial strains). The effects of these variables on adhesion were then separately evaluated by analyses of variance. The analyses revealed that the number of attached cells was significantly higher $(P<0.001)$ for the industrial strains than for the clinical strains. Strain origin (seafood or cheese industry) and sampling location (food or food environment) had a significant effect $(P<0.001)$ on adhesion of $L$. monocytogenes, but the colonized surface (polystyrene or stainless steel) had no effect $(P=0.847)$ on adhesion. A strong correlation ( $r=0.64$ ) was found between adhesion to poly-
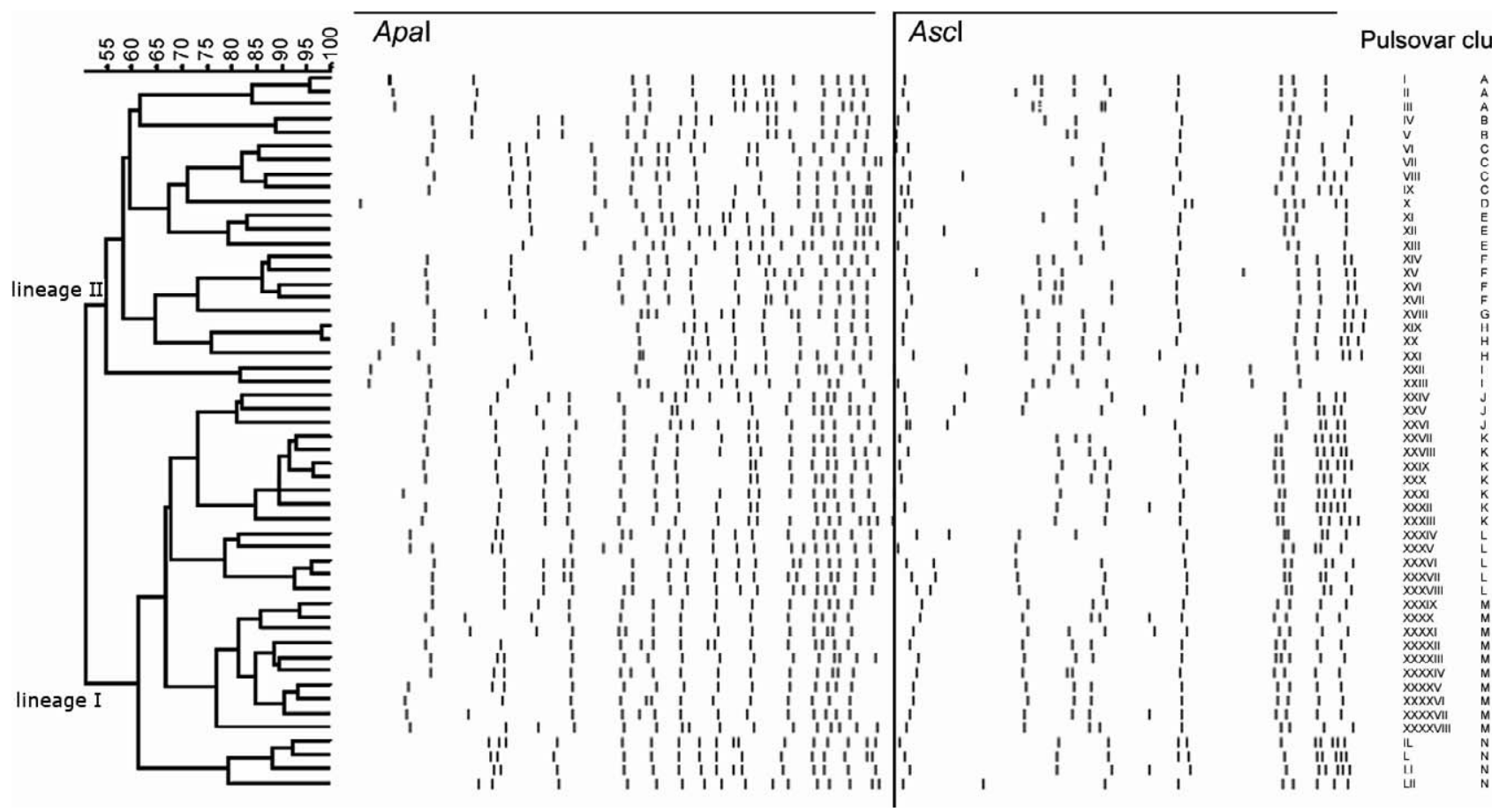

FIGURE 1. UPGMA dendrogram of L. monocytogenes strains based on the PFGE analysis of fragments obtained with enzymes ApaI (first column) and AscI (second column). Numbers LI and LII indicate the resulting pulsotype, and letters A through $N$ represent the PGFE clusters based on 77\% Dice coefficient similarity. 


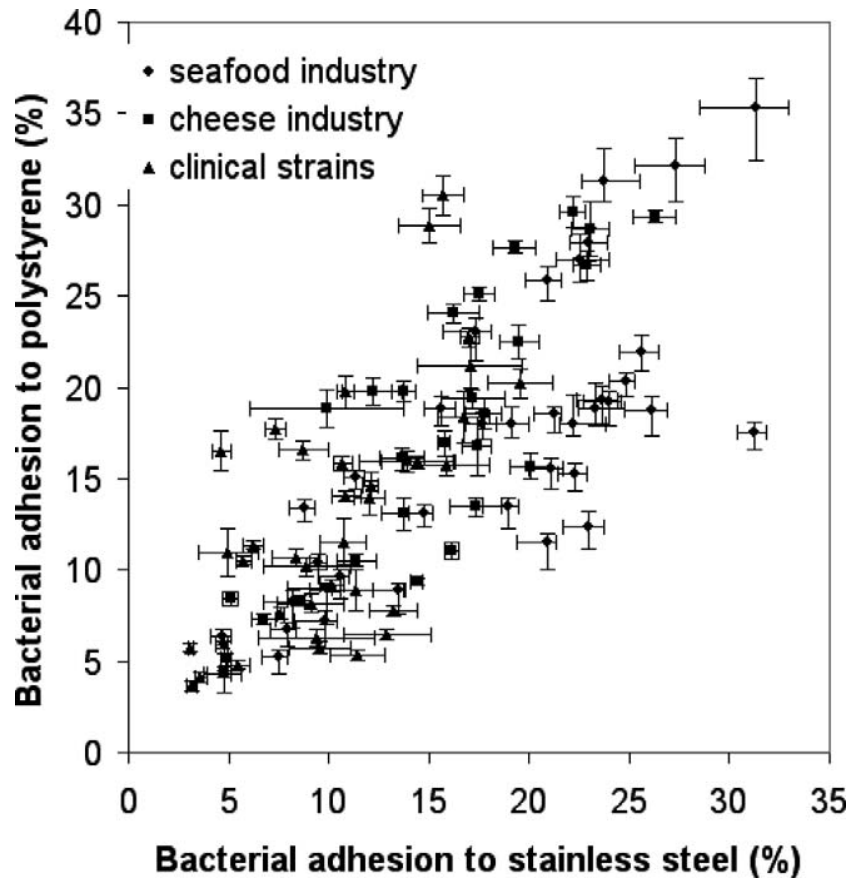

FIGURE 2. Correlation between adhesion of 101 L. monocytogenes strains to polystyrene and stainless steel surfaces.

styrene and to stainless steel surfaces for all strains (Fig. $2)$. In general, adhesion to polystyrene and stainless steel was not significantly different $(P>0.05)$. However, integration of the interactions (order 2 of the analysis of variance) highlighted some significant differences. Significant effects on adhesion $(P<0.001)$ were noted for all interactions, except for those between the sampling location and colonized surface $(P=0.011)$. The specific analysis of variance for the clinical strains also indicated a significant difference $(P<0.001)$ in adhesion for all variables and all interactions at order 2 . The interactions with significant differences are plotted in Figure 3.

No difference in adhesion to inert surfaces was observed between sporadic and epidemic L. monocytogenes strains (Fig. 3a). However, strains isolated directly from seafood were more likely to attach to inert surfaces than were strains isolated from the seafood environment. However, strains originating from the cheese environment exhibited greater adherence than did strains isolated directly from the cheese (Fig. 3a). The plots of the interactions revealed that the clinical strains attached more readily to polystyrene than to stainless steel, whereas the industrial strains adhered similarly to polystyrene and stainless steel (Fig. 3b). Although cells of sporadic strains attached in higher numbers to polystyrene than to stainless steel (Fig.

FIGURE 3. Plotted order-2 interactions based on analysis of variance for adhesion of $101 \mathrm{~L}$. monocytogenes strains to polystyrene (PS) and stainless steel (SS). (a) Colonized surface and strain origin; (b) strain origin and contamination type or sampling location; and (c) contamination type or sampling location and colonized surface. Error bars indicate the $95 \%$ confident intervals based on analysis of variance.

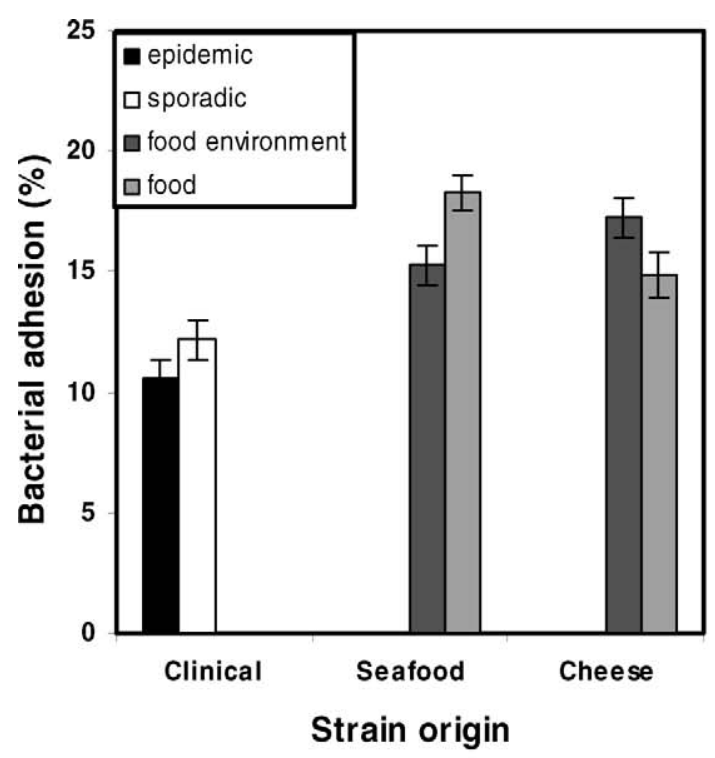

(a)

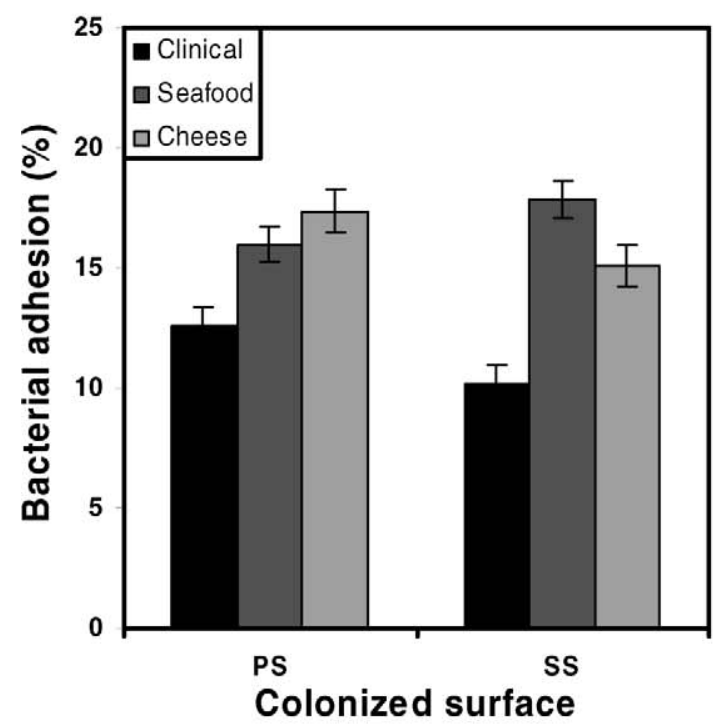

(b)

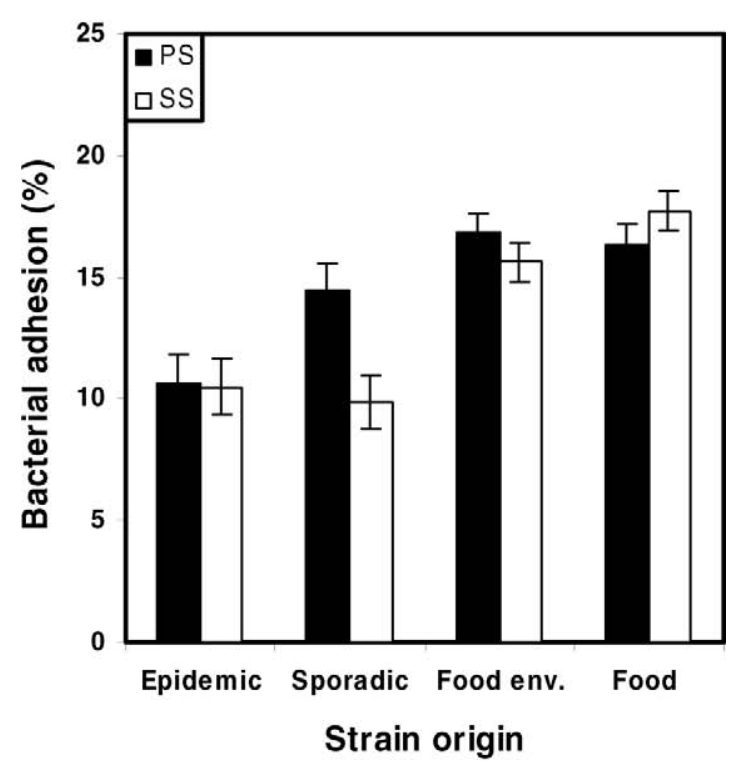

(c) 


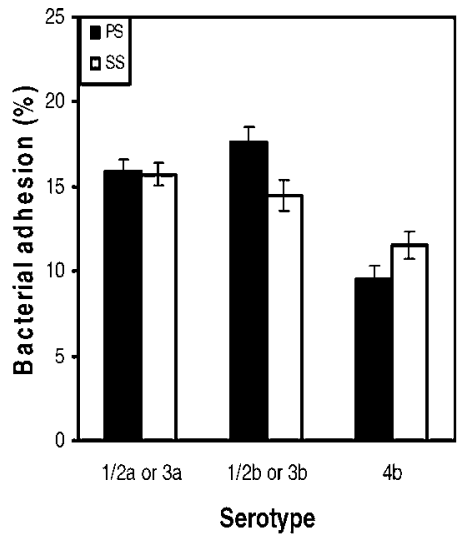

(a)

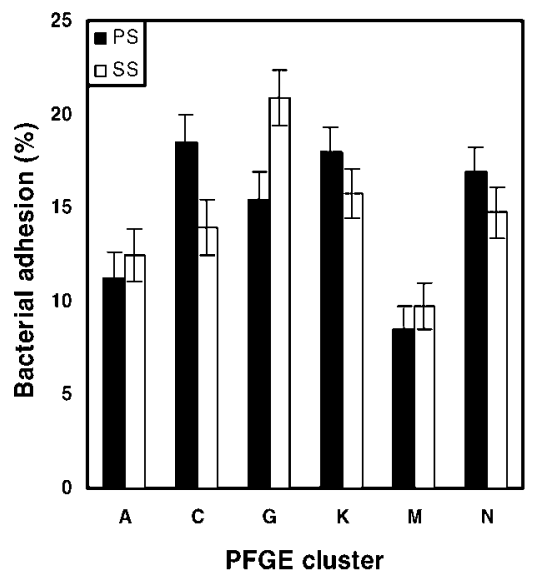

(c)

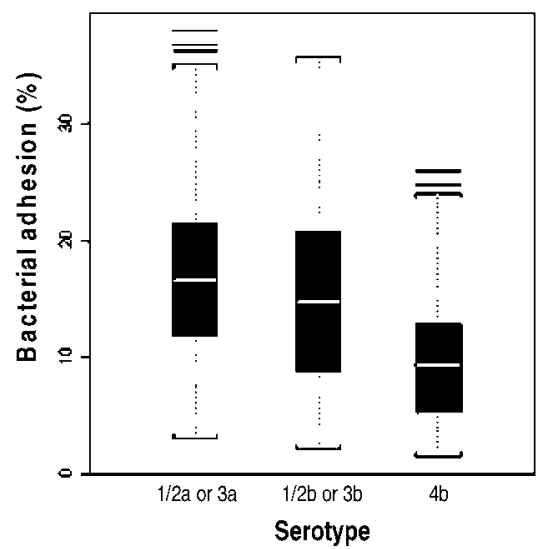

(b)

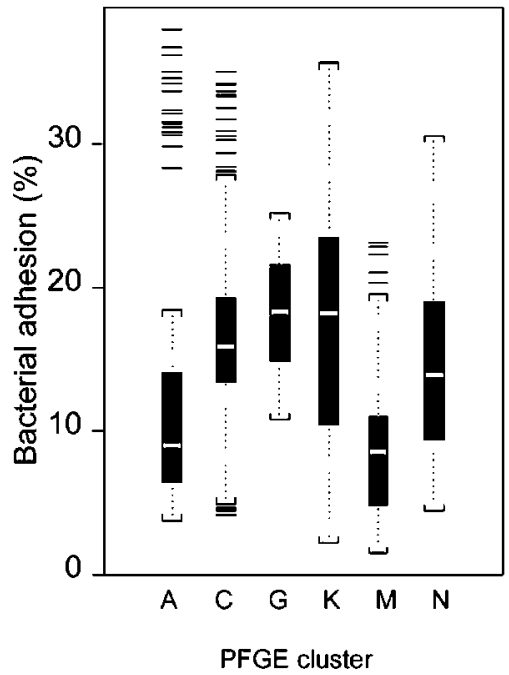

FIGURE 4. Adhesion of L. monocytogenes strains based on serotype $(a, b)$ and PFGE clusters $(c, d)$ that included 10 or more strains. $(a, c)$ Plotted interaction from analysis of variance. $(b, d)$ Distribution analysis. The white lines indicate the median, the boxes are limited by the first and third quartiles Q1 and Q3 (25 and 75\% of data below these values, respectively), the whiskers contain values between $Q 1$ $1.5(Q 3-Q 1)$ and $Q 3+1.5(Q 3-Q 1)$, and outer values appear as individual lines.

3c), no difference in adhesion was seen based on the source of the industrial (seafood or cheese) and clinical (sporadic or epidemic) strains.

Adhesion based on PFGE cluster and serotype. Cluster analysis revealed that serotype and pulsotype were dependent, as demonstrated with divisions I (serotypes $1 / 2 \mathrm{~b}$ or $3 \mathrm{~b}, 4 \mathrm{~b}$, and $4 \mathrm{e}$ ) and II (serotypes $1 / 2 \mathrm{a}$ or $3 \mathrm{a}$, and $1 / 2 \mathrm{c}$ ) (Fig. 1). Consequently, the effect of pulsotype and serotype on adhesion were analyzed separately. Because the number of strains represented in each PFGE cluster or each serotype was heterogeneous, it was difficult to statistically compare adhesion among all clusters and serotypes. Therefore, only PFGE clusters or serotypes with at least 10 strains were analyzed. A significant effect $(P<0.001)$ on strain adhesion was noted among the serotypes and PFGE clusters (Fig. 4) for both industrial and clinical strains. The statistical (Fig. 4a) and distribution (Fig. 4b) analyses among the serotypes revealed that serotype $4 \mathrm{~b}$ strains were less adherent to both surfaces than were strains of serotypes $1 / 2 \mathrm{a}$ or $3 a$ and $1 / 2 b$ or $3 b$. Considering the PFGE clusters with at least 10 strains (A, C, G, K, M, and N), the statistical (Fig. 4c) and distribution (Fig. 4d) analyses revealed that the strains from clusters $\mathrm{A}$ and $\mathrm{M}$ were less adherent to both surfaces than were strains belonging to clusters $\mathrm{C}, \mathrm{G}, \mathrm{K}$, and N. Cluster A was composed of serotype 1/2a and $3 \mathrm{a}$ strains from the seafood industry and a clinical case, whereas cluster $\mathrm{M}$ contained cheese industry strains and clinical isolates of serotypes $4 \mathrm{~b}$ and $4 \mathrm{e}$.

\section{DISCUSSION}

A total of $101 \mathrm{~L}$. monocytogenes isolates from the seafood and cheese industries and human clinical listeriosis cases were tested using the 96-well microtiter plate technique for their ability to adhere to two different materials. Two colonized surfaces (stainless steel and polystyrene) were selected to evaluate the effect of surface properties on strain adhesion. To quantify adhesion to stainless steel, two microtiter plates manufactured from stainless steel and commercially available 96-well polystyrene microtiter plates were used as models. The polystyrene microtiter plate had the following surface properties as previously described: $41.8 \mathrm{~mJ} / \mathrm{m}$ Lifshitz-van der Waals energy $\left(\gamma_{\mathrm{s}}{ }^{\mathrm{LW}}\right)$, $4.7 \mathrm{~mJ} / \mathrm{m}$ Lewis electron-donor energy $\left(\gamma_{\mathrm{S}^{-}}\right)$, and $1.1 \mathrm{~mJ} / \mathrm{m}$ Lewis electron-acceptor energy $\left(\gamma_{\mathrm{S}}{ }^{+}\right)$, indicating that the surface was hydrophobic and uncharged (35). Characterization of the stainless steel microtiter plate in this study in- 
dicated that the surface was slightly hydrophobic and negatively charged.

All strains exhibited at least $3.10 \%$ adhesion to both surfaces. This result is in accordance with those of Kalmokoff et al. (18) and Lunden et al. (23), who found that L. monocytogenes adhered to stainless steel coupons after $2 \mathrm{~h}$ of contact. Because adhesion is the first step in biofilm formation, these findings support the ability of $L$. monocytogenes to form biofilms on inert surfaces $(3,9,13,28)$. A strong correlation was found between adhesion to polystyrene and adhesion to stainless steel, although the physicochemical surface properties of the polystyrene and stainless steel plates were different. Adhesion of L. monocytogenes to various surfaces such as stainless steel, polypropylene, and glass was previously observed $(17,24)$. By comparing the adhesion of one L. monocytogenes strain to various surfaces, Beresford et al. (2) also found that the surface had a limited effect on adhesion. Similar results were obtained by Chae et al. (10), who found that the surface properties of the cells and the substrata did not significantly influence adhesion of $L$. monocytogenes. The intrinsic ability of $L$. monocytogenes to adhere to inert surfaces is therefore stronger than the influence of the physicochemical surface properties.

Among the 101 strains examined, some significant variations were seen in the number of cells that attached to inert surfaces (from 3.10 to $35.29 \%$ ). Consequently, the effects of several variables were investigated for their contribution to the adhesion of L. monocytogenes to both surfaces. Environmental variables (strain origin and sampling location) were selected to evaluate the impact of strain history. Isolates from the food-processing environment were separated from food isolates to assess the impact of environment on adhesion. Clinical isolates from sporadic or epidemic cases of human illness also were assessed for adhesion. Serotyping was chosen to characterize the flagellar antigens that reflect the cell surface chemistry. PFGE analysis was used to estimate the impact of genotype on adhesion of a broad-range of L. monocytogenes strains, which has not been done before.

By integrating these variables, weak but significant adhesion differences were found among the strains according to the colonized surface and strain source. Greater adhesion of sporadic clinical strains to polystyrene than to stainless steel was seen, whereas no differences were observed between the two surfaces for the epidemic or industrial strains. Chae et al. (10) noticed higher crystal violet absorbance for sporadic strains than for epidemic strains attached to polystyrene microtiter plates after $1 \mathrm{~h}$ of incubation at $37^{\circ} \mathrm{C}$.

For the industrial strains, no significant difference in adhesion was noted between the seafood or cheese industry isolates nor was the percentage of attached cells significantly different between polystyrene and stainless steel. However, within the seafood and cheese industry isolates, some significant differences in adhesion were observed between the food and environmental isolates. Fewer attached cells were observed for the seafood environmental compared with the seafood isolates, whereas greater attachment was seen for cheese environmental compared with cheese isolates. This difference could be explained by the processes used in each industry and/or by the food per se, which could enhance or limit adhesion of L. monocytogenes. For example, in the seafood industry, the environmental strains were collected from floors, salt hoppers, drain grids (for unpacking, salting, and thawing), scorpion fish containers, balances, rugs of store boxes, and store boxes, whereas in the cheese factories, samples were collected from floors in brine rooms, wood and stainless steel shelves in cheese maturing cellars, brine containers, wood churns, and starter cultures. Because it was not specified whether the food was contaminated before or after processing, it was not possible to determine the effect of food. Further analyses should be conducted to investigate these effects.

All L. monocytogenes strains were characterized by serotyping and pulsotyping. Although the multiplex PCR assay did not distinguish serotype $1 / 2$ a from serotype $3 a, 1 / 2 b$ from $3 b, 1 / 2 c$ from $3 c$, and $4 b$ from $4 d$ and $4 e$, it did distinguish serotypes $1 / 2 \mathrm{a}, 1 / 2 \mathrm{~b}, 1 / 2 \mathrm{c}$, and $4 \mathrm{~b}$, which constitute $98 \%$ of the food, environmental, and clinical isolates (14). The serotype distribution for the 101 strains is similar to that reported previously: serotype $4 \mathrm{~b}$ strains are most commonly recovered from patients, whereas serotypes $1 / 2 \mathrm{a}$ and $1 / 2 \mathrm{~b}$ are most frequently encountered in food-manufacturing facilities $(20,30)$. Based on pulsotypes, the 101 strains could be classified into 14 PFGE clusters. Serotypes 1/2a (or $3 a$ ) and $1 / 2$ c were included in PFGE clusters $J$ through $\mathrm{N}$ and serotypes $1 / 2 \mathrm{~b}$ (or $3 \mathrm{~b}$ ), $4 \mathrm{~b}$, and $4 \mathrm{e}$ were included in PGFE clusters A through I. Genotypic analyses have consistently grouped $L$. monocytogenes into two major lineages (39). Multilocus enzyme electrophoresis divided the species into division I (serotypes $1 / 2 \mathrm{~b}, 4 \mathrm{a}$, and $4 \mathrm{~b}$ ) and division II (serotypes $1 / 2 \mathrm{a}$ and $1 / 2 \mathrm{c}$ ) (29). PFGE also yielded a binary division into lineage $\mathrm{I}$ (serotypes $1 / 2 \mathrm{~b}, 3 \mathrm{~b}, 4 \mathrm{~b}, 4 \mathrm{~d}$, and $4 \mathrm{e}$ ) and lineage II (serotypes 1/2a, 3a, 1/2c, and 3c). Consequently, clusters $\mathrm{J}$ through $\mathrm{N}$ represent lineage I and clusters A through I represent the lineage II. The serotype 1/2c strains corresponded to cluster $\mathrm{H}$. No strains from lineage III, which correspond to serotypes $4 \mathrm{a}$ and $4 \mathrm{c}$, were identified. These strains are isolated rarely from food-processing environments and patients (39). In this study, the PFGE cluster and serotype data sets were heterogeneous, making statistical analyses difficult. However, studies conducted on clusters with 10 or more strains revealed that serotype $4 \mathrm{~b}$ isolates were less adherent than were isolates of serotypes $1 / 2 a$ (or $3 a$ ) and $1 / 2 b$ (or $3 b$ ). Strains in clusters A and M were less adherent than those in clusters $\mathrm{C}, \mathrm{G}, \mathrm{K}$, and $\mathrm{N}$. Cluster A contained serotype 1/2a strains from the seafood industry and a clinical case, whereas cluster $\mathrm{M}$ contained serotype $4 \mathrm{~b}$ strains from clinical cases and serotype $4 \mathrm{e}$ strains from the cheese industry. Cluster A strains belong to lineage II, and cluster M strains belong to lineage I, and no significant difference in adhesion to either surface was noticed between the two lineages. This result suggests that low adhesion could not be related to a genetic lineage. Differences in survival between strains of serotypes $1 / 2 \mathrm{a}$ and $4 \mathrm{~b}$ in response to bacteriocins and heat already have been observed (7). Genomic comparisons have revealed that se- 
rotype $1 / 2$ a strains have a slightly larger genome than do serotype $4 \mathrm{~b}$ strains (27). Concerning adhesion to stainless steel, Lunden et al. (23) and Norwood and Gilmour (28) observed the highest levels of attachment for serotype $1 / 2 \mathrm{c}$ strains as compared with serotypes $1 / 2 \mathrm{a}, 1 / 2 \mathrm{~b}$, and $4 \mathrm{~b}$. However, Kalmokoff et al. (18) did not observe a direct correlation between the serotype of $L$. monocytogenes and attachment to stainless steel. In this study, the weakest adhesion was attributed to serotype $4 \mathrm{~b}$ strains as compared with strains of serotypes $1 / 2 \mathrm{a}$ (or $3 \mathrm{a}$ ) or $1 / 2 \mathrm{~b}$ (or $3 \mathrm{~b}$ ). However, serotype $1 / 2 \mathrm{a}$ strains in cluster $\mathrm{A}$ and serotype $4 \mathrm{~b}$ strains in cluster $\mathrm{M}$ both displayed weak adhesion, indicating that the serotype cannot be used to distinguish between weakly and strongly adhering strains. Conversely, the clinical isolates were less adherent than were the industrial isolates. Therefore, strain origin and PFGE cluster analysis may be more useful than serotyping for assessing adhesion. Using pulsotyping to categorize adhesion in L. monocytogenes, Lunden et al. (22) also found that adherence of PFGE type I was significantly stronger than that of other PFGE types. Further experiments with a larger set of known pulsotypes belonging to clusters $\mathrm{A}, \mathrm{M}, \mathrm{C}, \mathrm{G}, \mathrm{K}$, and $\mathrm{N}$ should be performed to explore this conclusion.

Adhesion to both polystyrene and stainless steel was highly correlated, indicating that the physicochemical properties of the colonized surface are not a determining factor for adhesion of $L$. monocytogenes cells. The industrial isolates adhered more readily to inert surfaces than did the clinical strains. Adhesion was more closely related to genetic variation, as indicated by PFGE cluster analysis, than to specific flagellar antigens, as demonstrated by serotyping.

\section{ACKNOWLEDGMENTS}

The authors thank Anne-Marie Jandos, Véronique Lebret, and Guylaine Leleu for their technical assistance and Jacky Six for his assistance in the design of the stainless steel plate. This work was supported by grants from the Région Nord-Pas de Calais (France) and FEDER.

\section{REFERENCES}

1. Autio, T., R. Keto-Timonen, J. Lunden, J. Bjorkroth, and H. Korkeala. 2003. Characterisation of persistent and sporadic Listeria monocytogenes strains by pulsed-field gel electrophoresis (PFGE) and amplified fragment length polymorphism (AFLP). Syst. Appl. Microbiol. 26:539-545.

2. Beresford, M., P. Andrew, and G. Shama. 2001. Listeria monocytogenes adheres to many materials found in food-processing environments. J. Appl. Microbiol. 90:1000-1005.

3. Borucki, M., J. Peppin, D. White, F. Loge, and D. Call. 2003. Variation in biofilm formation among strains of Listeria monocytogenes. Appl. Environ. Microbiol. 69:7336-7342.

4. Briandet, R., V. Leriche, B. Carpentier, and M. Bellon-Fontaine. 1999. Effects of the growth procedure on the surface hydrophobicity of Listeria monocytogenes cells and their adhesion to stainless steel. J. Food Prot. 62:994-998.

5. Briandet, R., T. Meylheuc, C. Maher, and M.-N. Bellon-Fontaine. 1999. Listeria monocytogenes Scott A: cell surface charge, hydrophobicity, and electron donor and acceptor characteristics under different environmental growth conditions. Appl. Environ. Microbiol. 65:5328-5333.

6. Bryers, J. 2000. Biofilm formation and persistence. Wiley-Liss, New York.

7. Buncic, S., S. Avery, J. Rocourt, and M. Dimitrijevic. 2001. Can food-related environmental factors induce different behaviour in two key serovars, $4 \mathrm{~b}$ and $1 / 2 \mathrm{a}$, of Listeria monocytogenes? Int. J. Food Microbiol. 65:201-212.

8. Carpentier, B., and O. Cerf. 1993. Biofilms and their consequences, with particular reference to hygiene in the food industry. J. Appl. Bacteriol. 75:499-511.

9. Chae, M., and H. Schraft. 2000. Comparative evaluation of adhesion and biofilm formation of different Listeria monocytogenes strains. Int. J. Food Microbiol. 62:103-111.

10. Chae, M., H. Schraft, L. Truelstrup Hansen, and R. Mackereth. 2006 Effects of physiochemical surface characteristics of Listeria monocytogenes strains on attachment to glass. Food Microbiol. 23:250259.

11. Chavant, P., B. Martinie, T. Meylheuc, M. Bellon-Fontaine, and M. Hebraud. 2002. Listeria monocytogenes LO28: surface physicochemical properties and ability to form biofilms at different temperatures and growth phases. Appl. Environ. Microbiol. 68:728-737.

12. Dice, R. 1945. Measures of the amount of ecologic association between species. Ecology 26:297-302.

13. Djordjevic, D., M. Wiedmann, and L. A. McLandsborough. 2002. Microtiter plate assay for assessment of Listeria monocytogenes biofilm formation. Appl. Environ. Microbiol. 68:2950-2958.

14. Doumith, M., C. Buchrieser, P. Glaser, C. Jacquet, and P. Martin. 2004. Differentiation of the major Listeria monocytogenes serovars by multiplex PCR. J. Clin. Microbiol. 42:3819-3822.

15. Farber, J., and P. Peterkin. 1991. Listeria monocytogenes, a foodborne pathogen. Microbiol. Rev. 55:476-511.

16. Graves, L., and B. Swaminathan. 2001. PulseNet standardized protocol for subtyping Listeria monocytogenes by macrorestriction and pulsed-field gel electrophoresis. Int. J. Food Microbiol. 65:55-62.

17. Hood, S., and E. Zottola. 1997. Adherence to stainless steel by foodborne microorganisms during growth in model food systems. Int. J. Food Microbiol. 37:145-153.

18. Kalmokoff, M., J. Austin, X. Wan, G. Sanders, B. Banerjee, and J. Farber. 2001. Adsorption, attachment and biofilm formation among isolates of Listeria monocytogenes using model conditions. J. Appl. Microbiol. 91:725-734.

19. Kerouanton, A., A. Brisabois, E. Denoyer, F. Dilasser, J. Grout, G. Salvat, and B. Picard. 1998. Comparison of five typing methods for epidemiological study of Listeria monocytogenes. Int. J. Food Microbiol. 43:61-71.

20. Khatariou, S. 2002. Listeria monocytogenes virulence and pathogenicity, a food safety perspective. J. Food Prot. 65:1811-1829.

21. Lunden, J., T. Autio, and H. Korkeala. 2002. Transfer of persistent Listeria monocytogenes contamination between food-processing plants associated with a dicing machine. J. Food Prot. 65:11291133.

22. Lunden, J., T. Autio, A. Sjoberg, and H. Korkeala. 2003. Persistent and nonpersistent Listeria monocytogenes contamination in meat and poultry processing plants. J. Food Prot. 66:2062-2069.

23. Lunden, J., M. Miettinen, T. Autio, and H. Korkeala. 2000. Persistent Listeria monocytogenes strains show enhanced adherence to food contact surface after short contact time. J. Food Prot. 63:1204-1207.

24. Mafu, A., D. Roy, J. Goulet, and P. Magny. 1990. Attachment of Listeria monocytogenes to stainless steel, glass, polypropylene, and rubber surfaces after short contact times. J. Food Prot. 53:742-746.

25. Mafu, A., D. Roy, J. Goulet, and L. Savoie. 1991. Characterization of physicochemical forces involved in adhesion of Listeria monocytogenes to surfaces. Appl. Environ. Microbiol. 57:1969-1973.

26. Moreto, T., and S. Langsrud. 2004. Listeria monocytogenes: biofilm formation and persistence in food-processing environments. Biofilms $1: 107-121$.

27. Nelson, K., D. Fouts, E. Mongodin, J. Ravel, R. Deboy, J. Kolonay, D. Rasko, S. Angiuoli, S. Gill, I. Paulsen, J. Peterson, O. White, W Nelson, W. Nierman, M. Beanan, L. Brinkac, S. Daugherty, R. Dodson, A. Durkin, R. Madupu, D. Haft, J. Selengut, S. Van Aken, H Khouri, N. Fedorova, H. Forberger, B. Tran, S. Kathariou, L. Wonderling, G. Uhlich, D. Bayles, J. Luchansky, and C. Fraser. 2004. Whole genome comparisons of serotype $4 \mathrm{~b}$ and $1 / 2 \mathrm{a}$ strains of the food-borne pathogen Listeria monocytogenes reveal new insights 
into the core genome components of this species. Nucleic Acids Res. 32:2386-2395.

28. Norwood, D., and A. Gilmour. 1999. Adherence of Listeria monocytogenes strains to stainless steel coupons. J. Appl. Microbiol. 85: 576-582.

29. Piffaretti, J., H. Kressebuch, M. Aeschenbacher, J. Bille, E. Bannerman, J. Musser, R. Selander, and J. Rocourt. 1989. Genetic characterization of clones of the bacterium Listeria monocytogenes causing epidemic disease. Proc. Natl. Acad. Sci. USA 86:3818-3822.

30. Rocourt, J., C. Jacquet, and A. Reilly. 2000. Epidemiology of human listeriosis and seafoods. Int. J. Food Microbiol. 62:197-209.

31. Smoot, L., and M. Pierson. 1998. Effect of environmental stress on the ability of Listeria monocytogenes ScottA to attach to food contact surfaces. J. Food Prot. 61:1293-1298.

32. Stewart, P., G. McFeeters, and C. Huang. 2000. Biofilm control by antimicrobial agents, p. 373-405. In J. Bryers (ed.), Biofilms II: process analysis and applications. Wiley-Liss, New York.

33. Stopforth, J., J. Samelis, J. Sofos, P. Kendall, and G. Smith. 2002. Biofilm formation by acid-adapted and nonadapted Listeria monocytogenes in fresh beef decontamination washings and its subsequent inactivation with sanitizers. J. Food Prot. 65:1717-1727.
34. Swaminathan, B., T. Barrett, S. Hunter, and R. Tauxe. 2001 PulseNet: the molecular subtyping network for foodborne bacterial disease surveillance, United States. Emerg. Infect. Dis. 7:382-389.

35. Tresse, O., V. Lebret, T. Benezech, and C. Faille. 2006. Comparative evaluation of adhesion, surface properties, and surface protein composition of Listeria monocytogenes strains after cultivation at constant pH of 5 and 7. J. Appl. Microbiol. 101:53-62.

36. Tukey, J. W. 1977. Exploratory data analysis. Addison-Wesley, Reading, Mass.

37. van Oss, C., R. Good, and M. Chaundhury. 1988. Additive and nonadditive surface tension components and the interpretation of contact angles. Langmuir 4:884-891.

38. Vatanyopaisarn, S., A. Nazli, C. Dodd, C. Rees, and W. Waites. 2000. Effect of flagella on initial attachment of Listeria monocytogenes to stainless steel. Appl. Environ. Microbiol. 66:860-863.

39. Wiedmann, M., J. L. Bruce, C. Keating, A. E. Johnson, P. L. McDonough, and C. A. Batt. 1997. Ribotypes and virulence gene polymorphism suggest three distinct Listeria monocytogenes lineages with differences in their pathogenic potential. Infect. Immun. 65:2707-2716. 